January 2015

\title{
Information Behavior in the Mobile Environment: An Overview
}

Ziming Liu

San Jose State University, ziming.liu@sjsu.edu

Follow this and additional works at: https://scholarworks.sjsu.edu/ischoolsrj

Part of the Archival Science Commons, Cataloging and Metadata Commons, Collection Development and Management Commons, Community Psychology Commons, Experimental Analysis of Behavior Commons, Information Literacy Commons, Scholarly Communication Commons, and the Scholarly Publishing Commons

\section{Recommended Citation}

Liu, Z. (2016). Information Behavior in the Mobile Environment: An Overview. School of Information Student Research Journal, 5(2). https://doi.org/10.31979/2575-2499.050202 Retrieved from https://scholarworks.sjsu.edu/ischoolsrj/vol5/iss2/2

This article is brought to you by the open access Journals at SJSU ScholarWorks. It has been accepted for inclusion in School of Information Student Research Journal by an authorized administrator of SJSU ScholarWorks. For more information, please contact scholarworks@sjsu.edu. 


\title{
Information Behavior in the Mobile Environment: An Overview
}

\begin{abstract}
As smartphones become ubiquitous, they increasingly influence the way in which students seek and use information. It is important to understand emerging information behavior as a result of wide spread use of smartphones. This paper provides an overview of information behavior in the mobile environment. Gender differences in mobile information seeking are discussed. People interact with mobile information in varied and unpredictable locations or while in transit. The mobility of information engagement is an important issue that human information theory should embrace.
\end{abstract}

\section{Keywords}

smartphones, information behavior, mobile environment, mobility of information

\section{About Author}

Dr. Ziming Liu received his Ph.D. in library and information studies at the University of California at Berkeley in 1996. He has published widely in top-tier scholarly journals such as Annual Review of Information Science and Technology, Communications of the ACM, Information Processing and Management, Journal of the American Society for Information Science \& Technology, and Journal of Documentation. His book, Paper to Digital: Documents in the Information Age, is indicative of his research concerns. 


\section{Introduction}

The proliferation of Internet-capable mobile phones (or smartphones) has brought a significant change in information access. The wearability of smartphones enables communication while physically in motion. Smartphones are now poised to overtake desktop and laptop computers as the most common web-access device (Nicholas et al, 2013). They have become a vital device of anytime, anywhere access to information on the web for hundreds of millions users (Church et al, 2007).

The pervasiveness of mobile technology is forming "a distinct culture where learners repeatedly use mobility and awareness of their immediate context as starting points for keeping social contact alive, accessing fresh content, getting local information and becoming visible as creators and producers of content" (Kukulska-Hulme, 2010). As smartphones become ubiquitous, they increasingly influence the way in which students seek and use information. It is important to understand the emerging information behavior of students as a result of wide spread use of smartphones.

The ECAR study of undergraduate students and information technology, 2013 report reveals that $76 \%$ of undergraduate students in the United States own a smartphone, and smartphone ownership is even more common outside the U.S. (e.g., $81 \%$ in Canada). The report also indicates that students are ready to embrace their mobile devices more for academic purposes (Dahlstrom et al, 2013).

The motivation behind our project is to investigate information behavior in the mobile environment. A survey of 205 undergraduate students was conducted in China between November 2013 and February 2014. Undergraduate students in China were selected as the subjects of our study for three reasons: (1) They are young and educated, and always open to new technologies. Almost every undergraduate student in China today owns a smartphone. (2) They spend a significant amount of time on reading, and they frequently use their smartphones for many of their information activities. (3) Since undergraduate students in our survey are mostly 18-22 years old, the impact of generational differences on information behavior is kept to a minimum. This report highlights some of our findings.

\section{Motivations for Using Smartphones}

People often need information while on the move. Being mobile not only influences the types of information people seek, but also the strategies employed (Sohn et al, 2008).

Mills's study (2009) indicates that the majority of respondents at the University of Cambridge primarily use their smartphones to make calls, send text messages, and take pictures. A recent study of smartphone usage behaviors in Malaysia also reveals that nearly half (47\%) of respondents don't use their smartphones for blogging (Osman et al, 2012). Campbell and Park (2008) note that adolescents and young adults are known for their distinctive use of smartphones to establish and reinforce their social network ties. Smartphones play an important role in helping young people keep social contact alive and support them as creators of content.

Survey results of our project show that a large motivation for smartphone users in China is staying connected to social networks. Over $88 \%$ and $54 \%$ of survey respondents use their smartphones for WeChat--a mobile phone text and voice messaging communication service in 
China--and micro-blogging, respectively. In addition, browsing news, searching the web, and checking online dictionaries are also popular activities among these young smartphone users.

Female users are more likely than their male counterparts to use their smartphones for the purposes of micro-blogging (61.3\% vs. $45.7 \%)$, checking online dictionaries (64.0\% vs. $41.5 \%)$, reading novels $(40.5 \%$ vs. $25.5 \%)$, and sending pictures $(35.1 \%$ vs. $23.4 \%)$. These differences are statistically significant.

About one third of our survey respondents use smartphones for email, reading novels, and sending pictures. While students do some light reading on their smartphones, very few of them use their smartphones for academic purposes such as accessing library resources $(7.8 \%)$ and reading scholarly papers $(5.4 \%)$.

\section{Strategies to Cope with the "Always-On" Nature Of Mobile Devices}

Distraction is not a new problem, but the arrival of a mobile environment raises this issue to a new level of attention. Horrigan (2009) stresses that the "continual information exchange" in the mobile world could cause " 'serial digital distraction' as people respond to a slew of bits cascading to them."

The "always on" nature of mobile devices means users are constantly connected and always available. Nearly $60 \%$ of respondents in our survey constantly check their smartphones, while about $20 \%$ check their smartphones during class breaks, and $7 \%$ check them by the end of the day. One respondent notes: "Most people check their cell phones before brushing their teeth in the morning. I must admit that I am so reluctant to turn off my smartphone even when I am sleeping, especially if a response to a message is expected." Another respondent stresses: "Because of the real time nature of mobile communication, young people are expected to respond immediately. Replies sent 30 minutes later must be accompanied by an apology." It is interesting to note that female smartphone users tend to be more disciplined than male users when dealing with the "always on" nature of mobile information. Compared to $48.2 \%$ of female users, $72.3 \%$ of male users report that they check their smartphones constantly. A higher percentage of female users report that they check during class breaks $(28.2 \%$ vs. $11.7 \%)$ or simply ignore it $(17.3 \%$ vs. $8.5 \%)$. The differences are statistically significant $\left(\mathrm{X}^{2}=14.7\right.$, $p<0.01)$.

Continuous connectedness supports a sort of incremental social synchronization for plans, schedules, and progress (Dempsey, 2009). However, if continuous communication becomes pervasive, it will become a serious distraction. Walsh (2012) finds that people "constantly multi-tasked with their devices and found [the devices] acted as a serious distraction at times, even to the extent of preventing them from processing new information arriving. Before they could think about and process any piece of information it had been replaced by something newer, creating a large amount of transient, unused information." One female respondent in our survey indicates that in this constantly connected world, one must learn how to use discipline-- one must put off less essential needs until later, or simply ignore them. Another respondent warns: "Over connectedness will reduce time available for other activities such as physical exercise." He adds: "With the smartphone, it is so easy to ask for help. People may lose the spirit to do things independently." 


\section{Preferences for Devices/Media}

Church, Smyth, Cotter, and Bradley (2007) investigate the information behavior of European mobile Internet users. They find that $94 \%$ of sessions consist of just browsing. Dominated by the desire for quick, often context-specific information, the types of information people read while they are on the move are often factual and small. A recent study on information behavior in a mobile environment also finds that: "Any speculative information, information that needed reading in depth, or information that required further analysis was generally avoided" (Walsh, 2012).

Learners tend to move between devices for different parts of a learning task. Yarmey (2011) suggests that the "information literacy world would benefit from a closer parsing of when and why users switch between devices." People tend to read short texts on their smartphones, and read serious materials on other devices (e.g., desktop or laptop computers) or on paper. Survey results of our project clearly indicate that only a very small number of survey respondents prefer reading serious documents on their smartphones, accounting for $2.0 \%$ for reading research materials and $2.9 \%$ for teaching-related materials, respectively.

$14.6 \%$ of survey respondents like to read research materials, and $17.1 \%$ like to read teaching materials on their e-readers (e.g. Kindles) or tablets (e.g., iPads). Major reasons include bigger displays, a better reading experience, more functions, and ease in carrying. One respondent comments that: "Unlike the smartphone, the size of the iPad is ideal for reading."

Nearly half of the survey respondents prefer reading research materials on their desktop or laptop computers because of bigger screens, faster network speeds, and ease in editing, searching, navigating, downloading, and storing materials. One respondent indicates: "While the iPad is a good choice for reading, it is inadequate for writing. I would avoid it when writing a long document." Another respondent explains: "I like to use desktop or laptop computers when reading research materials because of the ease in accessing library materials and the convenience in opening file folders." It is interesting to note that nearly $65 \%$ of survey respondents prefer reading their research materials electronically, while only $35.1 \%$ prefer reading research materials on traditional paper media. Many participants cite their preferences for desktop or laptop computers because of the attachment and a better reading experience. It seems that the new generation that is growing up with new technologies is more adaptive to digital reading.

For teaching related materials (e.g., textbooks), however, $60 \%$ of survey respondents still prefer reading on printed media, because of ease in carrying and note-taking, a pleasant reading experience, in-depth and concentrated reading, repeated reading, and an attachment to tradition. Printed media remain an effective tool of learning. Unlike other popular reading materials, teaching materials (e.g., textbooks) have different content, much of which is unfamiliar. Furthermore, compared to reading for pleasure, teaching materials are read for learning and retention (Daniel \&Willingham, 2012). Konnikova (2014) notes: "People prefer physical books, not out of old-fashioned attachment but because the nature of the object itself has deeper repercussions for reading and comprehension."

While nearly $65 \%$ of the respondents prefer reading research materials electronically, only $40 \%$ of them want to read their teaching materials electronically (e.g., smartphones, tablets, e-readers, desktop or laptop computers). One possible explanation is that the survey subjects are undergraduate students who may pay greater attention to teaching materials (especially for 
examinations) than to research materials. Future research is needed to investigate the relationship of education levels with the choice of reading media.

Liu and Huang (2008) find that female readers demonstrate a stronger preference for and a greater reliance on paper as a reading medium than male readers. Female readers are more linear and thorough readers, while males are more active browsers. Survey results of our project consistently show that female readers have a stronger preference for research materials on paper than male readers $\left(42.3 \%\right.$ vs. $\left.26.6 \% . X^{2}=5.539, p<0.05\right)$ and with teaching materials $(66.7 \%$ vs. $\left.52.1 \% . \mathrm{X}^{2}=4.483, p<0.05\right)$. These differences are statistically significant.

\section{Circumstances of Reading on Smartphones}

Our study finds that smartphones enable students to make full use of fragmentary time to read. About $80 \%$ of survey respondents report that they read on their smartphones during class breaks or while waiting for people. The use of smartphones for reading is often stationary rather than completely mobile. Many participants in our survey read on their smartphones while they are in their dormitories $(75.6 \%)$ or studying in libraries or classrooms $(55.6 \%)$. It is interesting to note that a higher percentage of males report that they read on their smartphones when taking public transportation $(84.0 \%$ vs. $64.9 \%)$ or while in the restroom $(51.1 \%$ vs. $36.0 \%)$. These differences are statistically significant.

Burnett and Jaeger (2011) note that unprecedented access to information in ever more portable devices will likely reshape human information behaviors. People interact with mobile information in varied and unpredictable locations or while in transit. Because the wearability of smartphones enables communication while physically in motion, the contexts of information engagement become less definable (as opposed to being in homes and offices). The mobility of information engagement is an important issue that human information theory should embrace (Burford \& Park, 2014).

\section{Implications}

Smartphones are used predominantly for accessing news and connecting to social media. Very few students use their smartphones for academic purposes such as accessing library resources or research. While students use smartphones for reading e-books, much of this reading is recreational during their spare time. Scholarly reading is usually avoided.

Levy (1997) observes "a general societal trend toward shallow, more fragmented, and less concentrated reading" in the digital environment. The widespread use of smartphones has played an important role in elevating this trend to a new level. The distraction caused by the "always on" nature of mobile devices is likely to have serious implications for retention and learning. As noted by several students: "I read news headlines and blogs on my smartphones all day long. I try to avoid long texts if I can." The "reading avoidance" phenomenon is even more troubling, and we are beginning to see the consequences of this alarming trend. If students develop a habit of reading short texts such as blogs, how can they concentrate on reading serious materials for learning? In this constantly connected world, students must learn how to exercise self-control in order to be successful learners.

The younger generation is accustomed to instant information access. For libraries to relevant, they must redesign their services (Bomhold, 2013). People may argue that too few students use their smartphones for academic purposes to justify libraries dedicating resources for 
mobile users. However, if you ask young people today about information access, most of them will point to mobile devices such as smartphones or tablets (Nicholas et al, 2013). It is important for libraries to leverage the strengths of mobile technology and to balance traditional services with mobile delivery. Even though many mobile users will use desktop or laptop computers to access library resources, they will benefit from the availability of mobile-friendly library services. When targeting users on the move, information professionals should be aware that the needs and behaviors of smartphone readers are significantly different compared to users of fixed devices, and should provide services in a mobile-friendly way. It is also important to promote our services on social networks, given the social nature of mobile information (Walsh, 2012).

\section{References}

Bomhold, C. (2013). Educational use of smart phone technology. Program: Electronic Library and Information Systems, 47(4), 424-436.

Burford, S., \& Park, S. (2014). The impact of mobile tablet devices on human information behaviour. Journal of Documentation, 70(4), 622-639.

Burnett, G., \& Jaeger, P. (2011). The theory of information worlds and information behaviour. In A. Spink \& J. Heinström (Eds.), New directions in information behaviour (pp.161-180). London: Emerald Group Publishing Limited.

Campbell, S., \& Park, Y. (2008). Social implications of mobile telephony: The rise of personal communication society. Sociology Compass, 2(2), 371-387.

Church, K., Smyth, B., Cotter, P., \& Bradley, K. (2007). Mobile information access: A study of emerging search behavior on the mobile Internet. ACM Transactions on the Web, 1(1). Retrieved from http://dl.acm.org/citation.cfm?id=1232726

Dahlstrom, E., Walker, J.D., \& Dziuban, C. (2013). ECARS study of undergraduate students and information technology, 2013. Boulder, CO: EDUCAUSE Center for Applied Research.

Retrieved from http://www.educause.edu/library/resources/ecar-study-undergraduate-studentsand-information-technology-2013

Daniel, D., \& Willingham, D. (2012). Electronic textbooks: Why the rush?. Science, 355(6076), 1569-1571.

Dempsey, L. (2009). Always on: Libraries in a world of permanent connectivity. First Monday, 14(1). Retrieved from http://firstmonday.org/article/view/2291/2070

Horrigan, J. (2009). The Mobile difference: Wireless connectivity has drawn many users more deeply into digital life. Pew Internet and American Life Project. Retrieved from http://www.pewinternet.org/files/oldmedia/Files/Reports/2009/The_Mobile_Difference.pdf 
Konnikova, M. (2014, July 16). Being a better online reader. New Yorker. Retrieved from http://www.newyorker.com/science/maria-konnikova/being-a-better-online-reader

Kukulska-Hulme, A. (2010). Learning cultures on the move: Where are we heading?. Educational Technology \& Society, 13(4), 4-14.

Levy, D. M. (1997). I read the news today, oh boy: Reading and attention in digital libraries. In Proceedings of the 2nd ACM International Conference on Digital Libraries (pp. 202211). New York, NY: ACM Press.

Liu, Z., \& Huang, X. (2008). Gender differences in the online reading environment. Journal of Documentation, 64(4), 616-626.

Mills, K. (2009). M-Libraries: Information use on the move. Retrieved from http://arcadiaproject.lib.cam.ac.uk/docs/M-Libraries_report.pdf

Nicholas, D., Clark, D., Rowlands, I., \& Jamali, H. (2013). Information on the go: A case study of Europeana mobile users. Journal of the American Society for Information Science and Technology, 64(7), 1131-1322.

Osman, M., Talib, A., Sanusi, Z., Tan, S., \& Alwi, A. (2012). A study of the trend of smartphone and its usage behavior in Malaysia. International Journal on New Computer Architectures and Their Applications, 2(1), 275-286.

Sohn, T., Li, K., Griswold, W., \& Hollan, J. (2008). A diary study of mobile information needs. In CHI'08 Proceedings of the SIGCHI Conference on Human Factors in Computing Systems (pp.433-442). New York, NY: ACM.

Walsh, A. (2012). Mobile information literacy: A preliminary outline of information behaviour in a mobile environment. Journal of Information Literacy, 6(2), 56-69.

Yarmey, K. (2011). Student information literacy in the mobile environment. EDUCAUSE Review Online. Retrieved from http://www.educause.edu/ero/article/student-informationliteracy-mobile-environment 